UDC 37.013: 39

DOI: $10.31470 / 2415-3729-2018-8-80-95$

\title{
Verbal Methods of Personality Upbringing in Folk Pedagogy
}

\section{Tetiana Kochubei}

Doctor of the Sciences, Professor,

Professor of the Department of social pedagogy and social work,

Pavlo Tychyna Uman State Pedagogical University,

$\triangle 2$, Sadova Str., Uman, Cherkasy region, Ukraine, 20300

E-mail: udpu tania@ukr.net

ORCID: 0000-0002-9104-8442

\section{Вербальні методи виховання особистості у народній педагогіці}

\section{Тетяна Дмитрівна Кочубей}

доктор педагогічних наук, професор, професор кафедри соціальної педагогіки та соціальної роботи Уманський державний педагогічний університет імені Павла Тичини

$\triangle$ вул. Садова, 2, м. Умань, Черкаська область, Україна, 20300

Дата надходження статті: 01 серпня 2018 p. Стаття прийнята до друку: 25 листопада 2018 р.

\section{Abstract}

A thorough analysis of verbal methods of personality upbringing in folk pedagogy (lullabies, tales, fairy tales, poetry, caricature, and funny) has been carried out and their importance in the formation of the personality's moral and physical qualities from the early childhood has been proved. It was established that various genres of folklore influenced the emotional and sensual sphere of a personality by their 
imagery, and contributed to forming its beliefs. It has been proved that folklore performed adaptive, ideological, orientational and regulatory functions in relation to younger generations. It was discovered that the first folklore works which mother introduced a child were lullabies, where the inner world of the mother was revealed, her feelings, hopes and dreams were expressed, so as an anxiety about the future fate of her child, its health etc. The author notes that a talk (the mother made her wishes for the healthy physical development of her child, and its beautiful life) is considered as one of the most ancient forms of oral folk art. The influence of amusements on the process of preserving and strengthening the health of children, acting as a means of activating their motor activity were proved. It was established that a great role in shaping the ideal of human bodily perfection was played by fairy tales whose characters, as bearers of various human positive and negative qualities, as well as the content and morals of fairy tales, were formed in one case - a negative attitude to inadequate to the national ideal characteristics of the person's physical development, and in the other - a positive one. It was also noted that fairy tales formed an important part of folk pedagogical culture; the first mention of them belongs to the period of Kyivan Rus, but their origins were lost in the primitive society, when a person believed in its blood ties with different species of animals, in the miraculous actions of supernatural forces.

It has been proved that the effectiveness of the child's natural development and its health formation, in accordance with the system of popular knowledge, is under the influence of such components of the child's life as: a personal hygiene, a mode of life, a tempering of the organism, peculiarities of nutrition, established norms of behavior, etc.

The ways of effective use of the folk folklore potential are elucidated: focusing children's attention on the most significant features of nature objects and their influence on the child's physical development; the disclosure of the human body aesthetic beauty; the verbal guidance of children in relation to physical development; direct teachings, prejudices, prohibitions; a combination of physical content with appropriate ritual, musical, and game elements. It is substantiated that people's pedagogy developed distinct and clear notions about 
which moral and physical qualities should be upbrought in the child, the sequence of the use of those or other means of physical culture.

Key words: verbal methods of upbringing, folk pedagogy, folklore, lullabies, fairy tales, poetry caressing, funny, child's physical and moral development.

\section{References}

1. Egorova S. F., Pushkareva, L. N. \& Schapova, Ya. N. (Ed.). (1985). Antologiya pedagogicheskoy myisli Drevney Rusi i russkogo gosudarstva XIV-XVIII vv. [Anthology of the pedagogical thought of Ancient Russia and the Russian state of the XIV-XVIII centuries]. Moskva : Pedagogika [in Russian].

2. Artiukh, L. F., Balushok, V. H., Bondarenko, H. B. et al. (2008). Ukrainska kultura XIX stolittia [Ukrainian culture of the nineteenth century] (Vols. 1). Kyiv : Nauk. Dumka [in Ukrainian].

3. Afanasev, A. N. (1982). Drevo zhizni: izbrannyie stati [The Tree of Life: Selected Articles]. Moskva : Sovremennik [in Russian].

4. Blok, A. (1924). Byit i kultura drevnih slavyan [Life and culture of ancient Slavs]. Moskva [in Russian].

5. Boltarovych, Z. (1993). Tradytsii simeinoho vykhovannia [Traditions of family upbringing]. Narodna tvorchist ta etnohrafiia Folk art and etnography, 2, 16-44 [in Ukrainian].

6. Zapiski I. Belyaeva (1901) [Notes by I. Beliaev]. Moskva [in Russian].

7. Klish, I. (1992). Kozatska khrystyianska respublika [Cossack Christian Republic]. Kyiv : Dnipro [in Ukrainian].

8. Povalii, L. V. (1999). Vykhovannia u pidlitkiv povahy do batkiv zasobamy etnopedahohiky [Development of adolescents respect for parents by means of ethnopedagogy]. Extended abstract of candidates thesis. Kyiv: Instytut problem vykhovannia APN Ukrainy [in Ukrainian].

9. Rodynni zvychai ta obriady ukraintsiv (1903). [Homeland customs and ceremonies of Ukrainians]. Materialy ekspedytsii Materials of the expedition. F. 8-3. Od. zb. 182. 45 ark [in Ukrainian].

10. Russkie byilinyi staroy i novoy zapisi (1910). [Russian epics of the old and new record]. Vol. 170. Moskva [in Russian]. 
11. Sokolova, V. K. (1979). Vesenne-letnie kalendarnyie obryadyi russkih, ukraintsev i belorusov, XIX - nachalo XX v. [Spring-summer calendar rituals of Russians, Ukrainians and Belarusians, XIX - beginning of the twentieth century]. Moskva : Nauka [in Russian].

12. Sheyn, P. V. (1887). Materialyi dlya izucheniya byita i yazyika russkogo naseleniya severo-zapadnogo kraya [Materials for studying the everyday life and language of the Russian population of the north-western region]. Sankt-Peterburg. Vol. 1, part 1, 199-255 [in Russian].

13. Yaschurzhinskiy, H. (1893). Poverya i obryadnosti, rodinyi i krestinyi [Belief and ritual, homeland and christening]. Kievskaya starina - Kievan antiquity, XLII, 404-415 [in Russian].

\section{Вступ}

На сучасному етапі розвитку українського суспільства відбувається модернізація всієї системи освіти. Важливого значення при цьому надається народній педагогіці, за допомогою якої відбувалася передача суспільно-історичного досвіду молодшим поколінням словесними методами виховання. Саме у процесі продуктивного розвитку мови відбувалося формування усної народної творчості, а на ії основі - фольклору, що виступав основним засобом узагальнення життєвого досвіду, втіленням світогляду та педагогічної мудрості. За допомогою фольклору дитина поринала у процес пізнання світу, адже фольклор виступав адекватним його відтворенням. Ця обставина формувала жанрову тематику фольклору та його педагогічний зміст.

Різноманітні жанри фольклору своєю образністю впливали на емоційно-почуттєву сферу особистості, сприяли формуванню переконань у необхідності збереження та зміцнення здоров'я. Виділення дитячого фольклору в самостійну сферу усної народної творчості пояснюється його особливою педагогічною функціональністю i виявом у ньому особливостей дитячого світосприймання.

Через окремі зразки дитячого фольклору діти одержували перші настанови щодо збереження та зміцнення здоров'я. 
Фольклор виконував адаптивну, світоглядну, орієнтувальну та регулятивну функції по відношенню до молодших поколінь.

Вихованню дитини на засадах народної педагогіки особливого значення надавали О. Духнович та К. Ушинський, якими вперше у науковий обіг було введено термін «народна педагогіка». М. Стельмахович розглядав народну педагогіку як галузь емпіричних педагогічних знань i досвіду народу, В. Ликов досліджував проблеми етнопедагогіки у рамках педагогічної деонтології, вивченню надбань козацької педагогіки приурочені праці I. Кліш, В. Кузя, Ю. Руденка, 3. Сергійчука, історії української педагогіки та національного виховання Т. Алексєєнко, В. Кременя, О. Любара, Л. Повалій, Д. Федоренко, П. Щербаня та ін. Проте поза межами дослідження залишилася проблема вербальних методів виховання особистості у народній педагогіці.

Мета статті - здійснити грунтовний аналіз вербальних методів народної педагогіки при вихованні дитини, довести важливість їх при формуванні духовних та тілесних якостей особистості, починаючи 3 наймолодшого віку, та з'ясувати шляхи ефективного використання їх потенціалу у виховному процесі закладів освіти.

\section{Матеріал і методи досліджень}

Для досягнення поставленої мети та завдань використовувалися такі методи дослідження: теоретичні (аналіз та узагальнення), емпіричні.

\section{Результати та їх обговорення}

У грудному періоді життя дитини пріоритетне місце у вихованні займала мати. Вона доглядала за дитиною, няньчила, пестила, виховувала ii, розвивала духовні та фізичні якості. Тому доцільним було 3 цією метою використовувати народні засоби виховання - колискові пісні, за допомогою яких дитина вперше прилучалася до рідної мови; пестушки, якими супроводжувалися рухи немовляти; потішки, за допомогою яких розвивалася рухова активність дитини (пальчиків, ручок, ніжок) та забавлянки.

Тож, першими фольклорними творами, 3 якими мати знайомила дитину були колискові. У колискових піснях розкривався внутрішній світ матері. Вона виражала у них різні 
почуття, надіï і мрії, тривожилася про подальшу долю дитини, ii здоров’я. Народна педагогіка періоду Київської Русі враховувала те, що пізнавальна діяльність дітей 3 наймолодшого віку характеризується конкретністю й емоційністю. Тому у цілому ряді колискових пісень акцентується увага на позитивному впливі природи на процес збереження та зміцнення здоров'я дітей та їхній розвиток. Прикладом можуть бути такі слова 3 колискової, записаної у 1852 р. в Україні етнографом І. Беляєвим:

«...Сонце зійде, обігріє.

Роса впаде та й скупає.

Будуть пташки прилітати

Дитиноньку колихати...» (Записки И. Беляева, 1901:76).

Під впливом колискових дитина пізнавала звуки рідної мови, починала розуміти материнське звернення до неї, окремі явища в навколишньому середовищі. Перший обов'язок матері створити умови для спокійного сну дитини. Народна фантазія поклала ці функції на персоніфіковані образи - Сон, Дрімоту i Кота - їхнього помічника. Вважають, що кіт своїм муркотінням допомагає дитині заснути; це i зробило його популярним героєм колискових пісень. У колискових мати порівнює дитину 3 котиком, звертається до злих і добрих духів (Егорова, Пушкарева, \& Щапова, 1985:61-63).

Сон i Дрімота генетично пов'язані 3 міфологічними уявленнями східних слов'ян-язичників, у колискових піснях це поетичні образи 3 найкращими людськими рисами. Вони хочуть бути найближчими до дитини, розподіляють між собою обов'язки: «А ти будеш колихать, а я буду усиплять», «Ти лягай у голівоньку, а я в ніжки» та ін. Неслухняних дітей лякали Букою: «Не ходи - там Бука, Бука з’їсть» (Ящуржинский, 1893:407). Ці образи використовувалися для припинення негативних реакцій дитини. Про Дрімоту і Котика згадувалося в одній із самих давніх колискових, що зафіксована етнографами і в Україні, i в Росії, i в Білорусі - «Ой ходить сон коло вікон».

Колискові пісні наповнені великою любов’ю й ніжністю до дитини й не розраховані на стороннього слухача. Це надавало їм особливої відвертості у виражені найбільш глибоких материнських почуттів: «Колишу тя, мій синочку, давненько колишу, доки не 
вснеш, золотенький, я тебе не лишу» (Егорова, Пушкарева, \& Щапова, 1985:41).

Особливістю колискових пісень, як і інших видів дитячого фольклору, є алегорія. Через різноманітні життєві ситуації, повадки добре знайомих тварин тощо дитина отримувала перші уявлення про те, що таке «можна» й «не можна», сприймала ставлення своїх батьків до природи. Тому мова колискових пісень барвиста, приваблива, а сюжети прості та зрозумілі, насичені яскравими образами природи. Колискова розглядалася також і як особлива турбота матері про новонародженого - маля не повинно кричати: «Біда, як на дитину щось наслано, сухоти або якась хвороба. Тоді вже нічим не забавити іï, i не допоможеш біді, як не знаєш чого проти крикливиці» (Русские былины..., 1910:191). Через те існували різні профілактично-магічні обряди, мета яких - охороняти, зберігати життя i здоров'я новонародженої дитини. Аналіз народних магічних заклинань від дитячих хвороб показує, що шептання у переважній більшості звернені до Сонця, Води, Вітру, Місяця (Русские былины..., 1910:241).

Із давніх давен дитину колисали, вважаючи, що колисання «заспокоює дитину, сприяє іiі засинанню, компенсує безпомічність рухів немовлят, наче продовжує рух, якого дитина зазнавала в утробі матері, сприяє розвитку вестибулярного апарату, ростові та зміцненню організму дитини» [12]. Особливого значення надавали підбору деревини та виготовленню колиски в залежності від статі дитини та стану іiі здоров'я. Так, для хворої доньки виготовляли калинову колиску, для здорової - 3 «ясена чи верби». Притаманним для хлопчиків було виготовлення колиски 3 тополі (для неспокійних) або дуба чи явора (для спокійних та здорових). Щоб дитина не плакала вішали віночок 3 хмелю в узголов 1 колиски. Вважалося, що такі обереги для дитини наповнювали ii цілющою силою (Повалій, 1999).

3 великою любов'ю бралася мати за шиття сорочки для своєї дитини, про це співалося і в колисковій:

«...Ой люлю ми, люлю,

Шию ту кошулю,

Кошулю тоненьку,

На літо легеньку...» (Родинні звича..., 1903:арк. 26). 
Після того, як мати зшивала сорочку, то не відразу вдягала iii на дитину, а проводила магічні дії 3 метою знешкодження впливу на маленьку дитину злих духів.

Самою першою пелюшкою для дитини була сорочка батька (хлопчику) чи матері (дівчинці). Цим самим дитину охороняли від сил зла, адже на сорочці батьків вишивалися знаки, що означали Сонце, Землю, Небо, які мали охоронний зміст - дитину віддавали під захист богам Всесвіту. Сорочка шилась із безкінечними магічними запобіганнями: верхня частина - зображення Неба, Сонця; на рукавах - символи засіяного поля. Археологія дає нам відомості, що на одязі зображувався і нижній світ. Також на вишивках часто зображувались богині - Рожаниці, Макош, Лада. Наприклад, рожаниць вишивки зображують такими, якими ïх змальовують міфи мисливських племен: жінки 3 гіллястими лосиними чи оленячими рогами. Загалом, ритуальна вишивка у своєму найбільш високому вираженні містить цікаву композицію: у центрі - висока жіноча постать, що, мабуть, варто тлумачити як зображення Макоши, котра уособлює Матір-сиру-землю. По боках - дві вершниці (Лада й Леля), іноді з сохами за сідлом.

Правильно організований педагогічний вплив матері в період раннього дитинства, як зазначає І. Кліш (Кліш, 1992) відіграє значнішу роль у розвитку дитини, ніж у подальші роки iii життя. У цьому віці закладалися основи фізичного розвитку, цілеспрямованої поведінки, кращих якостей людини. Тому виховний вплив матері проявлявся не тільки через колискові пісні. Коло дитини мати також примовляла свої побажання на здоровий фізичний розвиток, гарне життя й т.п., заговорюючи бажане. Саме заговори у наші дні вважаються одним із найдавніших видів усної народної творчості. Це окрема стійка поетична формула або цілий добуток, побудований найчастіше на порівнянні реального 3 бажаним. Саме тому «заговір матері» $є$ найціннішою пам’яткою народних поглядів на роль матері в житті дітей, поетична розповідь про безмірну материнську любов. О. Блок назвав його «золотим словом» (Блок, 1924). Серце матері «здатне усмоктувати в себе всі квіти й звуки, дихати різноманіттям миру» і таємничих сил. Душа матері видюча й чуйна, у ній немає межі прагненню пізнати майбутнє сина, уберегти його від можливих нещасть i 
напастей, що зустрічатимуться на його життєвому шляху. Адже, як писав О. Блок, материнська любов виступає вищою таємницею, рідною стихією, квітами з безодні. У iї заговорі ми чуємо широку багатострунвну музику - від ніжних ліричних мелодій до дійсної лютої пристрасті (Блок, 1924).

Поезія пестування у народній педагогіці виникла у зв'язку 3 необхідністю в інших формах виховання, пов'язаних iз подорослішанням дитини. Свою назву пестушки отримали від слів «пестити», «тішити», відомих здавна. Термін «пестун» був прирівняний пізніше до слова «вихователь», яке трапляється на сторінках літописів. Текст однієї пестушки був знайдений А. Мединцевою на стіні Новгородського Софійського собору. Запис датується XII - першою половиною XIII ст., головним персонажем виступає птах, предмет його піклування приготування каші, якою годували дітей (Соколова, 1979:81). Це, наприклад, може бути пестушка Сорока-Ворона. Такі пестушки дуже багаті й різноманітні за своїм звуковим оформленням. Ось, наприклад, пестушка, що була записана дослідником А. Будиловичем (1878 р.), яка нагадує спів птахів: «Дир-дир, диркач загубив плескач...» (Болтарович, 1993).

Аналіз текстів пестушок дає змогу виділити головні їхні особливості: швидкий ритм, гумористичний зміст, пов'язаний 3 різними рухами дітей.

Слід зазначити також про вплив забавлянок на процес збереження та зміцнення здоров'я дітей, бо вони були засобом активізації їх рухової активності. Граючись, дитина оволодівала життєво необхідними основними рухами. Наприклад, iї поступово переводили від колискової до погойдування у сидячому положенні на колінах, приспівуючи: «Гойда, гойда, гойдаша, де кобила - там лоша...». Отже, наші предки знали, що саме рухова активність спонукає природний процес розвитку дитини. У них існував особливий шар фольклору, який точно повторював ритмічність одноманітних простих рухів дитини першого року життя. Приміром, дорослий, тримаючи дитину на руках, імітував рухи підстрибування, примовляючи:

«Гук - гуки, гуки - гук

Наварила баба щук. 
Діточок годувала,

Ще й спатоньки повкладала».

Звісно, що така забава була стимулом для активізації рухової активності. Під час того, як дитина просиналася, наші предки стимулювали iï рухову активність такою забавлянкою, як потягування тіла, розпрямлення рук і ніжок:

«Потягусі, потягусі -

На дитину ростусі!

Скоріш в поміч ставала,

Скоріш мамі помагала!».

Коли дитина підростала, у період пестування, головну виховну роль відігравали старі жінки. За словами А. Афанасьєва, саме бабусі прилучали дітей до пізнання рослинного і тваринного світу шляхом збирання у лісі ягід, цілющих трав (Афанасьев, 1982:93). Діти знайомилися з їхніми ознаками, збирали разом із ними у певну пору року, вчилися їх розпізнавати. Такий виховний вплив бабусь закладав потребу в розумінні природи та середовища існування людини.

Велику роль у формуванні ідеалу людської тілесної досконалості відігравали казки. Персонажі казок, як носії різних людських i позитивних, і негативних якостей, а також, зміст i мораль казок, формували як негативне так і позитивне ставлення до фізичного розвитку людини відповідно до сформованого ідеалу.

Казки складали важливу частину народної педагогічної культури. Перші згадки про них належать до періоду Київської Русі, але витоки їх губляться у первісному суспільстві, коли людина вірила у свої кровні зв'язки з різними видами звірів, у чудесні дії потойбічних сил. Пізніше народ став використовувати казку як засіб виховання дітей. У казці зображувався гарний світ, який живе згідно зі своїми казковими законами, де діють незвичайні герої, де світло, правда й справедливість за допомогою істот, наділених фантастичною фізичною силою, перемагають зло, несправедливість, брехню. Педагогічна ефективність казок підсилювалася багатством поетичних засобів - наявністю епітетів, діалогів, динамічних подій, які робили казку привабливою. Адже, головною ознакою казок була не установка на вигадку, а те, що за допомогою фантазії розкривалася «життєва правда». Крім 
цього, дитячі казки взагалі відрізняються своєї безбожністю, вони врятовані від образів святих. Відсутність у казках цих персонажів свідчить про охорону народною педагогікою дитячої свідомості від раннього впливу релігії.

Казка була для дитини не лише прикладом доброї поведінки, а й зразком способу досягти певного фізичного розвитку, наприклад стати мужнім і сильним. До прикладу, такими є казки «Котигорошко», «Іван - мужицький син» та ін. У них зміст казки має життєво-практичне призначення, оскільки показує яким чином фізична сила й відвага героїв може допомогти здолати негаразди, покращити життя, досягти суспільного благополуччя. У них говориться про чоловічу відвагу, силу, сміливість, мужність, непоборність, які завжди допомагали богатирям подолати ворога. Богатирі, що вершать суд і встановлюють правду - це ідеал людської мужності. 3 цією метою у казках змальовувалися образи лицарів та козаків, як приклад для наслідування мужності, гідності, хоробрості тощо.

Особливого значення у казках набувають жіночі образи (ніжна і любляча мати, берегиня роду, гарна господиня тощо). Прикладом можуть слугувати казки «Кобиляча голова», «Дідова дочка i бабина дочка». Натомість, 3 гордої та чванькуватої, нахабної та лінивої «бабиної дочки» - народ завжди насміхається. Отже, казка прославляє й гарний фізичний розвиток дівчини, як запоруку виховання фізично здорової, працьовитої жінки.

Таким чином, деякі казки являють собою оригінальне зібрання повчань фізичного виховання дітей, зразкової фізичної форми.

Проте, доведеним $€$ той факт, що народом гостро висміювалися вади фізичного розвитку людини, зокрема фізичні надмірності: «Достанеться стиду-бриду цілувати повновиду», «Гладка така, що й миша не одержиться», «Роз’їхалась, як вершина». Тобто уявлення про тілесну досконалість в народній педагогіці грунтувалися як на позитивних так i на негативних характеристиках тієї чи іншої якості людини. Тимчасом, тілесний ідеал дівчини найчастіше пов'язувався із природною красою, граціозністю, стрункою i пружною ходою тощо, a хлопця 3 фізичною силою, хоробрістю, мужністю, сміливістю, 
що асоціювалися 3 образами сокола чи орла («Знати сокола по польоту, а молодця - по походці») (Артюх, Балушок, Бондаренко та ін., 2008).

Суттєва роль у формуванні фізичного ідеалу хлопця в народній педагогіці належала саме вихованню чоловічих якостей: «Запашний хлопець», «Здоровий, як лось», «Прездоровий, як дубовий пеньок», «Здоровий, як бугай». Важливою ознакою народних уявлень про адекватний розвиток фізичних якостей хлопця $\epsilon$ те, що рухові якості розглядалися як важливий, але не єдиний фактор людської фізичної досконалості.

Слід відмітити, що серед народу цінувалися не лише гострий розум, але й фізичні якості людини: «Де розуму не стає, там сила добуває» тощо. Крім фізичних якостей народна мудрість великого значення надавала таким позитивним рисам і якостям як сила, міць, дужість та протилежним - покірність, м'якість, слабкість, що представлені фразеологізмами: «Такий, як хліб м'який», «Де сила, там і міць» та ін. Деякі близькі до фразеологізмів прислів'я відтворюють у негативному розумінні людську аморфність: «Ні Богові свічка, ні чортові кочерга», «Ні права, ні гава» тощо (Артюх, Балушок, Бондаренко та ін., 2008).

Отже, в народній уяві людина ніколи не розглядалася лише як сукупність фізичних характеристик, а представлялася як цілісна трьохвимірна особистість (психічна, духовна і фізична). Проте, народом стан здоров'я людини оцінювався за зовнішніми показниками, зокрема тим, як вона виглядає: «Глянь на вид та й здоров'я не питай». Антитезою, протилежністю до здорового стану людини, за народним повір'ям, виступала хвороба: «Хвороба нікого не красить» тощо. У народному уявленні хвороба виступала страшнішою за смерть: «Не смерть страшна, а недуга». Тобто, сприймаючи смерть як природний момент завершення земного існування людини в Богом визначений термін, народна уява сприймала хворобу як непритаманне, неприродне явище. 3 метою формування здорового способу життя українським народом була вироблена система профілактичних засобів, про що свідчить поширене в народі прислів'я: «Бережи здоров'я замолоду, а честь - під старість» (Артюх, Балушок, Бондаренко та ін., 2008). Таким чином, в основу формування тогочасного ідеалу людської 
досконалості лягли чіткі приписи поведінки, та всього спектра життєдіяльності людини.

У народній мудрості великого значення надавали генотипним факторам розвитку дитини, тобто генетичній спадковості, яка впливала на природній розвиток особистості, формування ii якостей (розумових і фізичних), здоров'я (тілесного, психічного, соціального) тобто передачею від батьків до дітей спадкових якостей. Свідченням цього $є$ афоризми: «Яка хата, такий тин, який батько, такий син», «Який вродився, такий i вдався», «Криве дерево не дужо випрямитись», «Яблучко від яблуньки недалеко відкотиться», «Які самі, такі й сини», «Яка неня, така й доня» та ін. (Артюх, Балушок, Бондаренко та ін., 2008). Важливо, що народні уявлення, народні погляди на генетичну спадковість передбачали передачу від батьків до дітей не лише фізичних спадкових ознак, а й моральних і духовних. Це, в свою чергу, зумовлювало формування комплексу відповідальності батьків за наступне покоління, його первинні природні задатки.

Система народних знань підкреслює, що велику роль у розвитку дитини, формуванні іiі як повноцінної особистості відіграють такі складові ії життєдіяльності: режим дня, особиста гігієна, загартування, якісне харчування тощо.

\section{Висновки}

У народному фольклорі виробилися чіткі й ясні уявлення про те, які духовні та тілесні якості слід виховувати в дитині, починаючи 3 наймолодшого віку, про послідовність використання тих чи інших засобів фізичної культури. Протягом тривалого часу складалися ідеали людської досконалості. Завдяки різним фольклорним жанрам постійно відбувалася передача знань про зміцнення та збереження здоров'я, формування переконань, ціннісних орієнтацій у системі «людина-природа» шляхом: акцентування уваги дітей на найсуттєвіших ознаках об'єктів природи та впливу їх на фізичний розвиток дитини; розкриття естетичної краси тіла людини; словесного направляння дітей у ставленні до фізичного розвитку; прямих повчань, упереджень, заборон; поєднання фізичного змісту з відповідними обрядовими, музичними, ігровими елементами. 
Подальші наукові розвідки доцільно спрямувати на 3'ясування впливу ідей народної педагогіки на формування у молоді гуманного ставлення та поваги до людей похилого віку.

\section{Література}

1. Антология педагогической мысли Древней Руси и русского государства XIV-XVIII вв / под. ред. С. Ф. Егорова, Л. Н. Пушкарева, Я. Н. Щапова. Москва : Педагогика, 1985. $366 \mathrm{c}$.

2. Артюх Л. Ф., Балушок В. Г., Бондаренко Г. Б. та ін. Українська культура XIX століття. Київ : Наук. думка, 2008. Кн. 1. 707 c.

3. Афанасьев А. Н. Древо жизни: избранные статьи. Москва : Современник, 1982. 464 с.

4. Блок А. Быт и культура древних славян. Москва, 1924. 84 c.

5. Болтарович 3. Традиції сімейного виховання. Народна творчість та етнографія. 1993. № 2. С. 16-44.

6. Записки И. Беляева. Москва, 1901. № 15. 32 с.

7. Кліш I. Козацька християнська республіка. Київ : Дніпро, 1992. 495 с.

8. Повалій Л. В. Виховання у підлітків поваги до батьків засобами етнопедагогіки: автореф. дис. ... канд. пед. наук: 13.00.01 / Інститут проблем виховання АПН України. Київ, 1999. 16 c.

9. Родинні звичаї та обряди українців. Матеріали експедиції 1903 р. Ф. 8-3. Од. зб. 182. 45 арк. № 170 .

10. Русские былины старой и новой записи. Москва, 1910.

11. Соколова В. К. Весенне-летние календарные обряды русских, украинцев и белорусов, XIX - начало XX в. Москва : Наука, 1979. 288 с.

12. Шейн П. В. Материалы для изучения быта и языка русского населения северо-западного края. Санкт-Петербург, 1887. Т. 1, ч. 1. С. 199-255.

13. Ящуржинский X. Поверья и обрядности, родины и крестины. Киевская старина. 1893. Кн. XLII. С. 404-415. 


\section{Кочубей T.}

\section{Вербальні методи виховання особистості у народній педагогіці}

\section{Анотація}

Здійснено грунтовний аналіз вербальних методів виховання особистості у народній педагогіці (колискові пісні, казки, поезії пестування, забавлянки). Встановлено, що різноманітні жанри фольклору своєю образністю впливали на емоційно-почуттєву сферу особистості, сприяли формуванню у неї переконань. Доведено, що фольклор виконував адаптивну, світоглядну, орієнтувальну та регулятивну функції по відношенню до молодших поколінь. 3'ясовано шляхи ефективного використання потенціалу народного фольклору: акцентування уваги дітей на найсуттєвіших ознаках об'єктів природи та впливу їх на фізичний розвиток дитини; розкриття естетичної краси тіла людини; словесного направляння дітей у ставленні до фізичного розвитку; прямих повчань, упереджень, заборон; поєднання фізичного змісту 3 відповідними обрядовими, музичними, ігровими елементами. Обгрунтовано, що у народній педагогіці виробилися чіткі й ясні уявлення про те, які духовні та тілесні якості слід виховувати в дитині, про послідовність використання тих чи інших засобів фізичної культури.

Ключові слова: вербальні (словесні) методи виховання, народна педагогіка, фольклор, колискові пісні, казки, поезія пестування, забавлянки, фізичний і духовний розвиток дитини.

\section{Кочубей $\mathrm{T}$.}

\section{Вербальные методы воспитания личности в народной педагогике}

\section{Аннотация}

Осуществлен анализ вербальных методов воспитания личности в народной педагогике (колыбельные песни, заговоры, сказки, поэзии пестования, потешки) и доказана важность их при формировании духовных и телесных качеств личности. Выявлено, что первыми фольклорными произведениями, с 
которыми мать знакомила ребенка были колыбельные песни, в которых выражались чувства матери, ее надежды и мечты, тревога о дальнейшей судьбе ребенка, его здоровье. Доказано влияние забавлянок на процесс сохранения и укрепления здоровья детей, которые выступали средством активизации их двигательной активности. Установлено, что большую роль в формировании идеала человеческого телесного совершенства играли сказки, персонажи которых, а также содержание и мораль сказок формировали как негативное отношение к неадекватным национальным идеалам характеристик физического развития человека, так и положительное. Выяснено пути эффективного использования потенциала народного фольклора.

Ключевые слова: вербальные (словесные) методы воспитания, народная педагогика, фольклор, колыбельные песни, сказки, поэзия пестования, потешки, физическое и духовное развитие ребенка. 